\title{
Вариации водного потенциала листьев винограда различного происхождения в условиях Крыма (2014-2017 гг.)
}

Владимир Юрьевич Стаматиди, мл. науч. сотр. сектора физиологии селекционно-биотехнологического центра Федеральное Государственное бюджетное учреждение науки «Всероссийский национальный научно-исследовательский институт виноградарства и виноделия «Магарач» РАН», Россия, Республика Крым, г. Ялта, ул. Кирова, 31, 298600

\begin{abstract}
Приведены результаты мониторинга водных потенциалов листьев (ВП) шести сортов винограда в условиях юго-западной Предгорно-приморской зоны Крыма. Измерения ВП проводили по Сколандеру при помощи камеры давления. Установлено, что значения ВП за все годы мониторинга в течение вегетации постепенно увеличивались по модулю вплоть до начала созревания. Наиболее резкое увеличение ВП по модулю наблюдалось в начале созревания ягод, с последующим небольшим снижением в сентябре. В июне каждого года предутренние значения водных потенциалов составляли порядка -0.1 МПа, в июле около - 0.3 МПа, в августе - 0.6 МПа, в сентябре -0.5 МПа. Аналогичные изменения имеют место и у послеполуденных значений водных потенциалов: в июне они составляют порядка -1.0 МПа, в июле - 1.3 МПа, в августе - 1.5 МПа, в сентябре -1.4 МПа. Установлена достоверная разница в послеполуденных значениях ВП между сортами Мускат белый - Цитронный Магарача, Мускат черный - Альминский. Сортовые различия были статистически достоверными в 75\% случаев (три года из четырех лет исследований). Сделан вывод, что в условиях высоких температур и засухи растения сортов Цитронный Магарача и Альминский испытывают меньший водный стресс, чем Мускат белый и Мускат черный. Результаты исследований не выявили разницу между предутренними и послеполуденными водными потенциалами у сортов Рислинг рейнский - Рислинг Магарача.

Ключевые слова: эталонные сорта; сортааналоги; мониторинг водных потенциалов; камера давления.
\end{abstract}

$\mathrm{M}$ ноголетние наблюдения показывают, что виноградники Крыма кажАый второй год страдают от атмосферной и/ими почвенной засухи. Благодаря строгим научным результатам в настоящее время достоверно установмено, что именно водный дефицит является основной причиной низких урожаев виноградников полуострова [1-5]. Традиционный путь снятия водного стресса винограАников путем искусственного орошения не всегда возможен в современном Крыму,

\section{Как цитировать эту статью:}

Стоматиди В.Ю. Вариации водного потенциала листьев винограда различного происхождения в условиях Крыма (2014-2017 гг.)// «Магарач». Виноградарство и виноделие, 2019; 21(2); С. 133-137. DOI 10.35547/IM.2019.21.2.011

\section{To cite this article:}

Stamatidi V.Yu. Water potential variations in the leaves of vines of various origins in Crimea (2014-2017). Magarach Viticulture and Winemaking; 2019; 21(2); pp. 133-137. DOI 10.35547/IM.2019.21.2.011

удК 634.85:581.11/.45:58.087(470.75)

Поступила 16.08.2018

Принята к публикации 16.05.2019

(C) Авторы, 2019
O R I G I N A L A R T I C L E

\section{Water potential variations in the leaves of vines of various origins in Crimea (2014-2017)}

\author{
Vladimir Yuryevich Stamatidi \\ Federal State Budget Scientific Institution All-Russian National Research \\ Institute of Viticulture and Winemaking Magarach, Russian Academy of \\ Science, 31 Kirova Str., Yalta, Crimea, Russia
}

The article summarizes monitoring data on leaf water potential (WP) of six grapevine cultivars in the south-western piedmont-coastal zone of Crimea. WP has been measured in a pressure chamber using Scolander method. It was established that WP values over all the years of monitoring during the vegetation season gradually increased in absolute value until veraison. The most dramatic WP increase in absolute value was observed at veraison, followed by a slight decrease in September. In June of each year, the pre-dawn water potential values were around -0.1 MPa, in July around - 0.3 MPa, in August - 0.6 MPa, in September -0.5 MPa. The afternoon water potential values demonstrated similar changes: in June they were around -1.0 MPa, in July - 1.3 MPa, in August - $1.5 \mathrm{MPa}$, in September - 1.4 MPa. A significant difference was established in the afternoon WP values between varieties "Muscat Belyi" - "Tsitronny Magaracha”, “Muscat Chernyi' - 'Alminsky'. Varietal differences were statistically significant in $75 \%$ of cases (three years out of four years of research). It was found that under high temperatures and drought conditions, plants of the cultivars 'Tsitronny Magaracha' and 'Alminsky' undergo less water stress as compared to 'Muscat Belyi' and 'Muscat Chernyi'. The study results did not reveal any difference between the predawn and afternoon water potentials of 'Riesling of the Rhine' 'Riesling Magaracha' cultivars.

Key words: reference reference cultivars; alternative cultivars; water potential monitoring; pressure chamber.

испытывающим большой дефицит пресной воды. Особенно проблема нехватки воды в виноградарстве и в целом в сельском хозяйстве Крыма стала острой в последние годы. Сложившееся поможение вызвано как общепланетарными явлениями (растущий водный дефицит на фоне глобального потепления), так и сугубо местными (засушиивый регион, перекрытие Северо-Крымского канала, засоленность почв) [6]. МежАу тем хорошо известно, что степень устойчивости растений к водному дефициту варьирует как У разных видов, так и у разных сортов одного и того же вида [7-9]. В связи с этим возникает возможность уцучшения водного режима виноградников за счет учета сортовой специфики насажАений. Это в свою очередь вмечет необходимость оценки степени устойчивости растений разАичных сортов к водному стрессу и повышенным температурам.

В течение 2014 - 2017 годов в рамках аспирантуры ФГБУН «ВННИИВиВ «Магарач» РАН» автор изучал специфику воАного обмена и жаростойкости $\Lambda$ истьев некоторых кцассических и перспективных новых сортов винограда. Результаты исследований по жаростойкости были представлены нами ранее $[6,10-11]$. $\mathrm{B}$ настоящей работе представлены результаты мониторинга воАных потенциалов Аистьев шести сортов винограАа, их сезонной Аинамики в условиях юго-запаАной преАгорно-приморской зоны Крыма. 
Место и объекты исследования. Исследование проводилось на ампелографической колмекции в с.Вимино, ГУП «Агрофирма «Магарач»», юго-западная предгорно-приморская зона Крыма. Объектами исследований служили три перспективных новых сорта винограда (сорта-аналоги) и три кцассических сорта-эталона анамогичного направления использования урожая (табл 1).

Аанный набор сортов был рекомендован автору Аля изучения с позиций засухоустойчивости ампемографами и селекционерами Института «Магарач» и одобрен технологами и виноделами института при утвержАении пцана исследований на секции ученого совета (Аекабрь, 2013). Перспективные сорта взяты не случайно, а именно как аналоги кмассических сортов, отАичающиеся большей устойчивостью К возАействию вредителей и болезней. И хотя в целом новые сорта селекции института «Магарач» зарекомендовали себя положительно, их водный режим, степень жаро -и засухоустойчивости до неАавнего времени не были изучены. Наши исследования имели целью помучения информации об этой стороне жизнеАеятельности новых сортов, перспективных Аля виноградарства Крыма. За время исследований растения на ампемографической колмекции не орошались и по нашим наблюдениям ежегодно испытывали температурный и водный стресс в той или иной степени

Методы исследования. Основным физиологическим параметром, принятом последние 50 мет во всем мире при характеристике водного режима растений, явмяется водный потенциал тканей и органов (чаще всего Аистьев и побегов) растений. Наиболее распространенным и хорошо апробированным методом определения водного потенциала Аистьев сосудистых растений явцяется метоА измерения воАного потенциала с помощью камеры давления по Сколандеру [12]. Этот метод можно считать стандартным в современном растениеводстве.

Нами применялась следующая методика определения водных потенциалов мистьев винограда при помощи камеры давления, хорошо апробированная в условиях Крыма [13-15] :

1. Измерение водного потенциала $и$ истьев производят Ава раз в сутки: в предутренние часы 3:40-5:40 утра, когда значения водных потенциалов стабимьны и минимацьны по модулю, а также Анем в 12:30 - 14:00, когда абсолютные значения водных потенциалов так же относительно стабильны, но уже максимацьны по модуАю.

2. Аист выбирается без поврежАений, закончивший свой рост, но еще не начавший стареть. Обыч-

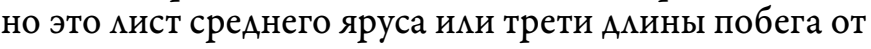
верхушки.

3. Острым мезвием делается срез черешка и быстро помещается в камеру давления таким образом, что $\Lambda$ итовая пцастинка находится внутри герметичной камеры, а черешок - с наружи. После этого в камеру медленно подается газообразный азот, что ведет к постепенному повышению давления в камере. Быстрая подача газа в камеру сушит мист и может привести к искажению действительной величины водного
Таблица 1. Объекты мониторинга водного режима в условиях ампелографической коллекции, с. Вилино, ГУП «Агрофирма «Магарач»», юго-западная предгорноприморская зона Крыма.

Table 1. Water potential monitoring objects in ampelographic collection, Vilino village, GUP Agrofirma Magarach, southwestern piedmont-coastal zone of Crimea.

\begin{tabular}{|c|c|c|}
\hline Сорт - эталон & Сорт - аналог & $\begin{array}{l}\text { Направ ение исполь- } \\
\text { зование урожая }\end{array}$ \\
\hline Мускат бемый & $\begin{array}{l}\text { Цитронный } \\
\text { Магарача }\end{array}$ & $\begin{array}{l}\text { Высококачественные } \\
\text { Аесертные вина }\end{array}$ \\
\hline Мускат черный & Ацьминский & $\begin{array}{l}\text { Высококачественные } \\
\text { Аесертные вина }\end{array}$ \\
\hline Рискинг Рейнский & Рислинг Магарача & $\begin{array}{l}\text { Высококачественные } \\
\text { сухие вина }\end{array}$ \\
\hline
\end{tabular}

потенциала миста. После того, как на кончике черешка начинает образовываться свежая капмя, регистрируются показания манометра, показывающего давление внутри камеры. Это значение (традиционно измеряемое в МПа или барах) интерпретируется как величина водного потенциала Аиста с обратным знаком.

4. Количество измерений водных потенциалов (количество анализируемых мистьев растений одного сорта) - 5 штук, количество наблюдаемых растений - 5 кустов кажАого сорта. Аћя статистической обработки Аанных использовались общепринятые в отечественном виноградарстве методические рекоменАации проведения полевого опыта и Аисперсионный анализ [16].

Резумьтаты мониторинга. В таблице 2 представмены результаты четырехлетнего мониторинга (2014 - 2017 гг) водных потенциалов мистьев винограда шести сортов винограда в условиях ампемографической коммекции, института «Магарач», с.Вимино, Республика Крым. Водный режим растений каждого сорта за конкретные сутки (гоА, месяц, число) характеризуется Авумя (максимацьным и минимацьным по модулю) значениями водных потенциалов кистьев: $\psi \mathrm{d}$ - послеполуденные значения (-МПа), $\psi \mathrm{p}$ - преАутренние значения (-МПа). Водные потенциалы преАставцены в таблице в виде средних значений по пяти измерениям и их ошибок.

1. Сезонные вариации водных потенциамов фистьев. Обращает на себя внимание существование ярко выраженной закономерности изменения как предутренних, так и послеполуденных значений воАных потенциалов Аистьев всех сортов в течение вегетации (табц.2).

Так, в июне каждого года предутренние значения водных потенциалов составцяют порядка $-0.1 \mathrm{MПа,}$ в июле $-0.3 \mathrm{MПа} \mathrm{(-0.2} \mathrm{МПа} \mathrm{в} 2014$ году и -0.4 МПа в 2016), в августе - $0.6 \mathrm{MПа,} \mathrm{в} \mathrm{сентябре}-0.5$ МПа. Аналогичные изменения имеют место и у послеполуАенных значений водных потенциалов: в июне они состав яют порядка - $1.0 \mathrm{MПа,} \mathrm{в} \mathrm{июле} \mathrm{-} 1.3 \mathrm{MПа,} \mathrm{в} \mathrm{ав-}$ густе - 1.5 МПа, в сентябре -1.4 МПа. Таким образом, имеет место увеличение по модуАю значений водных потенциалов вплоть Ао начаца созревания (начацо августа), резкое снижение водного потенциала в нача- 


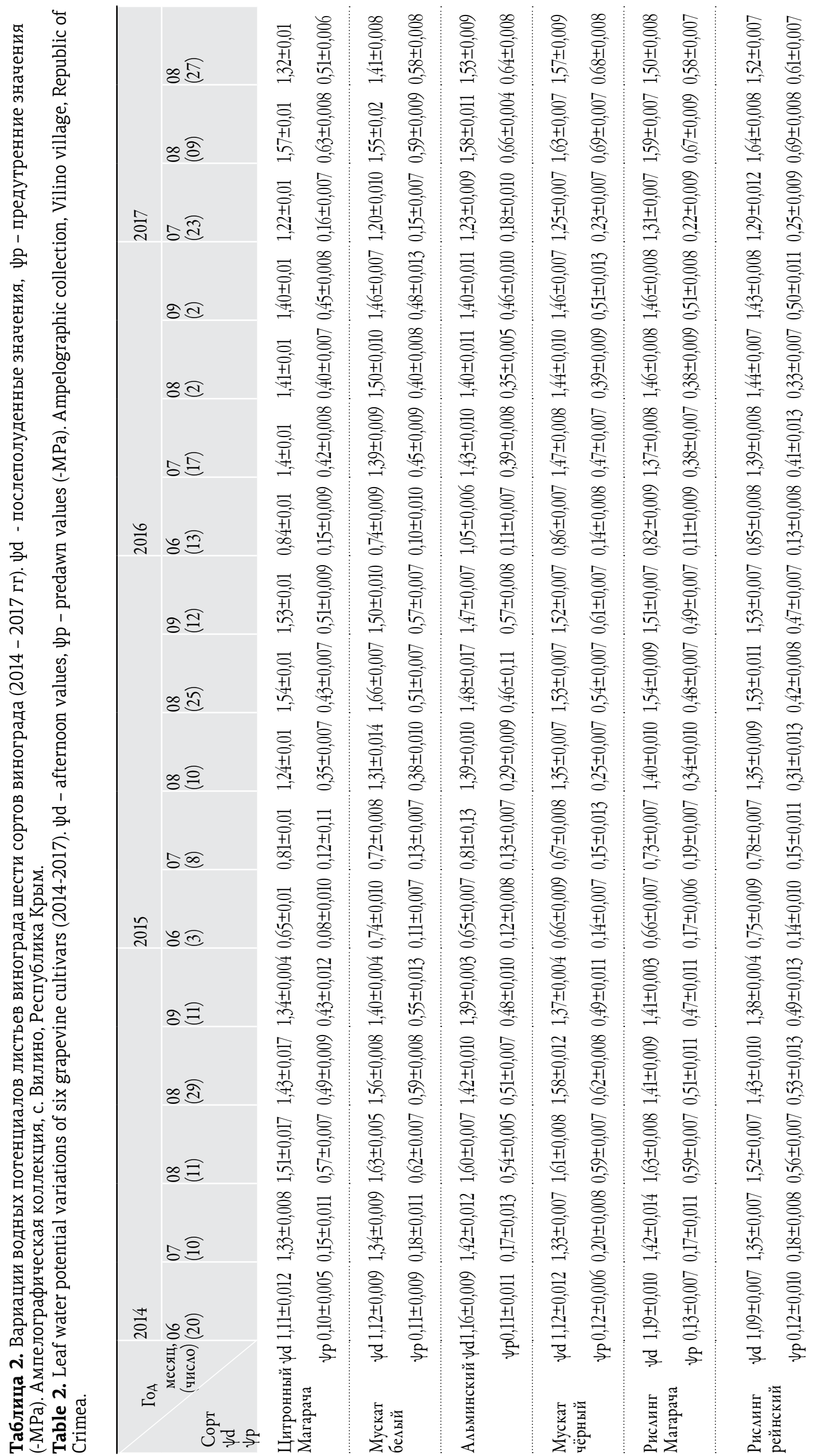


ме созревания ягод и, затем, некоторое снижение по модулю в сентябре. Подобная закономерность объясняется с одной стороны постепенным иссушением почвы в течении вегетации вплоть до середины августа в комбинации с высокими температурами и низкой влажностью воздуха. В сентябре напряженность атмосферной засухи (Аефицит Аавмения паров воды в атмосфере) падает, а эпизодические небольшие осаАки попоцняют нескоцько запас продуктивной вцаги в почве. С Аругой стороны следует отметить, что постепенное снижение водного потенциала мистьев винограда в течение вегетации и ,особенно, в начаме созревания ягоА, является естественным и набцюдается Ааже на хорошо орошаемых виноградниках [15, 17]. Об этой особенности водного режима винограда, преАставленной в терминах концентрации кцеточного сока $\Lambda$ итьев, сообщаци, в частности, такие известные специалисты, как Кондо И.Н., Стоев К.А. и ПуАрикова $\Lambda . П$ [18-19].

2. Вариации предутренних значений водных потенциалов мистьев ( $\psi$ p). Нами были установ ены достоверные сортовые разАичия в предутренних значениях водных потенциалов мистьев межАу некоторыми сортами-этацонами и сортами-анацогами (табц.3). В первую очередь это касается предутренних значений, максимацьных по модулю и характеризующих низкую вцажность почвы вызванную засухой (за все четыре года исследований эти значения были получены в августе, (табц. 2). Отдемьно эти данные представцены в таблице 3. Если принять во внимание, что изучаемые растения привиты на один подвой, а предутренние значения отражают влажность почвы в зоне активной части корневой системы, то этот резуцьтат набцюАений не явцяется тривиацьным. Аействитемьно, казамось бы, сортовая специфика Аолжна нивелироваться в условиях выровненной ампелографической комлекции с большим количеством сортов, преАставленных небольшим количеством растений каждого сорта. В этом случае слеАует ожидать относительной оАнородности вцажности почвы и предутренних значений воАных потенциалов мистьев. ОАнако, сортовые разАичия межАу парами Цитронный Магарача - Мускат бемый быми статистически достоверными в $75 \%$ случаев (3 года из 4 мет исслеАований), а Ацьминский - Мускат черный быми статистически достоверными в 100 $\%$ (все четыре года исследований) (табл.3). Последнее может быть связано с расположением активной части корневой системы у разАичных сортов в почвенных горизонтах разАичной влажности, т.е. разАичной архитектоникой корневых систем. Этот феномен, по нашему мнению, необходимо продолжить исследовать с привлечением более информативных методов (в первую очередь методологии фитомониторинга и математического моделирования), позвоцяющих без повреждений непрерывно следить за изменением параметров водного режима растений, в том числе и за водными потенциа ами мистьев $[13,20]$. Проведение прямых раскопок и непрерывный мониторинг вцажности почвы на разных гмубинах так же могмо бы помочь в понимании данного явления. В паре Рислинг Магарача - Рислинг Рейнский достоверных разАичий
Таблица 3. Средние значения максимальных по абсолютной величине предрассветных значений водных потенциалов листьев шести сортов винограда на основе данных табл.2, (-МПа).

Table 3. Mean values for maximum absolute predawn water potential values of the leaves of six grapevine cultivars based on the data from table $2,(-\mathrm{MPa})$.

\begin{tabular}{lccccc} 
Сорта винограда & 2014 & 2015 & 2016 & 2017 \\
\hdashline $\begin{array}{l}\text { Цитронный Мага- } \\
\text { рача }\end{array}$ & 0.57 & 0.51 & 0.45 & 0.63 \\
\hline Мускат бемый & 0.62 & 0.57 & 0.48 & 0.59 \\
\hdashline Альминский & 0.54 & 0.57 & 0.46 & 0.66 \\
\hdashline Мускат черный & 0.59 & 0.61 & 0.51 & 0.69 \\
\hdashline Рислинг Магарача & 0.59 & 0.49 & 0.51 & 0.67 \\
\hdashline Рислинг рейнский & 0.56 & 0.47 & 0.50 & 0.69 \\
\hdashline НСР $_{05}$ & 0.03 & 0.04 & 0.03 & 0.03
\end{tabular}

Таблица 4. Средние значения максимальных по абсолютной величине послеполуденных значений водных потенциалов листьев шести сортов винограда на основе данных табл.2, (-МПа).

Table 4. Mean values for maximum absolute afternoon water potential values of the leaves of six grapevine cultivars based on the data from table 2, (-MPa).

\begin{tabular}{lcccc}
\hline Сорта винограда & 2014 & 2015 & 2016 & 2017 \\
Цитронный Магарача & 1.51 & 1.54 & 1.41 & 1.57 \\
\hline Мускат бемый & 1.63 & 1.66 & 1.5 & 1.55 \\
\hline Альминский & 1.6 & 1.48 & 1.4 & 1.58 \\
\hline Мускат черный & 1.61 & 1.53 & 1.44 & 1.63 \\
\hline Рислинг Магарача & 1.63 & 1.54 & 1.46 & 1.59 \\
\hline Рислинг рейнский & 1.52 & 1.53 & 1.44 & 1.64 \\
\hline НСР $_{05}$ & 0.03 & 0.05 & 0.02 & 0.04 \\
\hline
\end{tabular}

на протяжении 3-х мет обнаружено не бымо. В первый год исследований 2014, (табл.3) максимацьные по моАулю предутренние значения сорта Рислинг Магарача были достоверно выше, чем у сорта Рислинг Рейнский. Таким образом немьзя сАелать вывод о более стабильном водном режиме сорта Рислинг Магарача в условиях засухи чем у сорта Рислинг Рейнский.

3. Вариации послеполуденных значений водных потенциамов мистьев ( $\psi$ p). Нами была установмены так же достоверные сортовые различия в послеполуАенных значениях водных потенциалов $и$ итьев межАу некоторыми сортами-этацонами и сортами-анацогами. В первую очередь это касается послеполуденных значений, максимацьных по модулю в связи с засухой и высокими температурами. За все четыре года исслеАований эти значения быми получены в августе, (табл. 2), отдецьно эти Аанные представцены в табц. 4. Сортовые разАичия межАу парами Цитронный Магарача - Мускат белый и Альминский - Мускат черный были статистически Аостоверными в $75 \%$ случаев (3 года из 4 мет исследований). В 2014 дия пары Цитронный Магарача - Мускат бемый, а в 2017 Аля пары Ацьминский - Мускат черный достоверных разцичий 
установцено не бымо (табц.4). Таким образом можно сделать вывод о том, что в условиях высоких температур и засухи растения сортов Цитронный Магарача и А^ьминский испытывают меньший водный стресс, чем соответственно Мускат бемый и Мускат черный. Этого немьзя утверждать относитемьно перспективного сорта Рислинг Магарача. Растения последнего чаще испытывали водный стресс, чем растения сорта Рислинг рейнский, особенно при воздействии атмосферной засухи (табм.4).

Представленные Аанные результатов четырехлетнего мониторинга водных потенциацов $\Lambda$ итьев шести сортов винограда позволяет сделать слеАующие вывоАы по сравнитемьной оценке водного режима изученных сортов.

\section{Выводы.}

1. Установцено, что водный режим сорта-анацога Цитронный Магарача более стабимен, чем водный режим сорта-эталона Мускат белый в условиях юго-запаАной преАгорно-приморской зоны Крыма при возАелывании без орошения. Растения сорта Цитронный Магарача испытывают меньший водный стресс, чем растения сорта Мускат бемый.

2. Установцено, что водный режим сорта-аналога Альминский более стабимен, чем водный режим сорта-этацона Мускат черный в условиях юго-западной преАгорно-приморской зоны Крыма при возАелывании без орошения. Растения сорта Альминский испытывают меньший водный стресс, чем растения сорта Мускат черный.

3. Результаты четырехлетних исследований не выявими существенных разАичий в значениях водных потенциацов $и$ стьев при воздействий высоких температур и засухи межАу сортом-анацогом Рислинг Магарача и сортом-эталоном Рислинг рейнский в усмовиях юго-запаАной преАгорно-приморской зоны Крыма.

4. Результаты четырехлетних исследований пока-

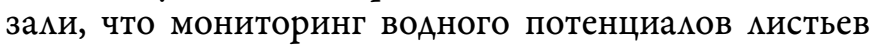
растений явцяется информативным инструментом оценки сортовой специфики водного режима винограда в условиях засухи и экстремацьно высоких температур.

\section{Источник финансирования}

Не указан.

\section{Financing source}

Not specified.

\section{Конфликт интересов}

Не заявмен.

\section{Conflict of interests}

\section{Not declared.}

\section{Список литературы / References}

1. Давитая, Ф. Ф. Климатические зоны винограда в СССР. / Ф. Ф. Давитая // М.: Пищепромиздат, 1958. - 192 с.

Davitaya F. F. Klimaticheskie zony vinograda v SSSR [Climatic zones of grapes in the USSR]. (in Russian)

2. Амирджанов, А. Г. Солнечная радиация и продуктивность виноградника. / А. Г. Амирджанов // Л.: Гидрометеоиздат, 1980. - 208 с.

Amirdzhanov A. G. Solnechnaya radiatsiva i produktivnost' vinogradnika [Solar radiation and vineyard productivity]. Leningrad, 1980. Pp.208. (in Russian)
3. Амирджанов, А. Г. Прогнозирование и программирование урожаев винограда. / А. Г. Амирджанов // Ялта, - 1988. - 108 с.

Amirdzhanov A. G. Prognozirovanie $i$ programmirovanie urozhaev vinograda [Prediction and programming of grapes harvests]. Yalta. 1988. P. 108. (in Russian)

4. Фурса, Д. И. Погода, орошение и продуктивность винограда / Д. И. Фурса. // Л.: Гидрометиоиздат, 1986. -199 с.

Fursa D. I. Pogoda, oroshenie i produktivnost' vinograda [Weather, irrigation and productivity of grapes]. Leningrad: Gidrometioizdat, 1986. P.199. (in Russian)

5. Дикань, А. П. Виноградарство Крыма. / А. П. Дикань, В. Ф. Вильчинский, Э. А. Верновский, И. Я. Заяц. Симферополь: Бизнес-Информ, 2001. - 408 c.

Dikan' A. P., Vil'chinskiy V. F., Vernovskiy E. A., Zayats I. Ya. Vinogradarstvo Kryma. [Viticulture of Crimea]. Simferopol: Biznes-Inform, 2001. P.408. (in Russian)

6. Стаматиди, В. Ю. Опыт сравнительной оценки жаростойкости листьев винограда в полевых условиях / В. Ю. Стаматиди // «Магарач». Виноградарство и виноделие. - 2017. - № 3. - С. 52-53.

Stamatidi V. Yu. Opyt sravnitel'noy otsenki zharostoykosti list'ev vinograda $v$ polevykh usloviyakh [Comparative assessment assay of grape leaf heat resistance under field conditions] // "Magarach". Viticulture and Winemaking. 2017. № 3. pp. 52-53. (in Russian)

7. Генкель, П. А. Пути и перспективы развития физиологии жаро- и засухоустойчивости культурных растений / П. А. Генкель // Сельскохозяйственная биология. - 1983. - № 1. -С. 15-24.

Genkel' P. A. Puti i perspektivy razvitiya fiziologii zharo- $i$ zasukhoustoychivosti kul'turnykh rasteniy [Ways and prospects for the development of physiology of heat and drought tolerance in cultivated plants] // Agricultural Biology. 1983. № 1. Pp. 15-24. (in Russian)

8. Шматько, И. Г. Физиологические различия реакции сортов пшеницы на изменение водообеспеченности и температуры / И. Г. Шматько, И. А. Григорюк, О. Е. Шведова // Физ.-б/х основы повышения продуктивности и устойчивости растений. - Кишинев, - 1986. - C. 28-34.

Shmat'ko I. G., Grigoryuk I. A., Shvedova O. E. Fiziologicheskie razlichiya reaktsii sortou pshenitsy na izmenenie vodoobespechennosti $i$ temperatury [Physiological differences in the reaction of wheat varieties to changes in water availability and temperature]. // Fiz.-b/kh osnouy pouysheniya produktivnosti i ustoychivosti rasteniy. - Kishenev, 1986. pp. 28-34. (in Russian)

9. Голодрига, П.Я. Перспективы генетики и селекции винограда на иммунитет. / Под ред. П.Я. Голодрига. - Киев: Наук. Думка, 1988. $-204 \mathrm{c}$.

Golodriga P.Ya. Perspektivy genetiki i selektsii vinograda na immunitet / Ed. P.Ya. Golodriga. Kiev: Nauk. Dumka, 1988. 204 p. (in Russian)

10. Стаматиди, В. Ю. Тестирование жаростойкости сортов винограда in vitro / В. Ю. Стаматиди, И. И. Рыфф // Экосистемы. - 2017. - № 11 (41). - C. 68-72.

Stamatidi V. Yu., I. I. Ryff. Testirovanie zharostoykosti sortov vinograda in vitro . "Ekosistemy". 2017. № 11 (41). pp. 68-72. (in Russian)

11. Стаматиди, В. Ю. Влияние засухи на урожай сортов винограда. / В. Ю. Стаматиди, И. И. Рыфф // Сборник материалов Годичного собрания Общества физиологов растений России, Всероссийской научной конференции с международным участием и школы молодых ученых. Иркутск, - 2018. - С. 730-732.

Stamatidi V. Yu., Ryff I. I. Vliyanie zasukbi na urozhay sortov vinograda. Sbornik materialov Godichnogo sobraniva Obshchestva fiziologov rasteniy Rossii, Vserossiyskoy nauchnoy konferentsii s mezhdunarodnym uchastiem i shkoly molodykh uchenykh [Proceedings of the Annual Meeting of the Society of Plant Physiologists of Russia, All-Russian Scientific Conference with International Participation and Schools of Young Scientists]. Irkutsk, 2018, pp. 730-732. (in Russian)

12. Scholander, P. F. Sap pressure in vascular plants / P. F. Scholander, H. T. Hammel, E. T. Brandstreet \& E. Hemmingsen // Science, -1965. - Р.339-346.

13. Методические основы оптимизации водного режима винограда в насаждениях / Нилов Н. Г., Рукопись.1993. - Ялта. - 300 с. 
Metodicheskie osnovy optimizatsii vodnogo rezhima vinograda $v$ nasazhdeniyakh. Nilov N. G., Rukopis'. [ Methodological basis for optimizing water regime of grapes in plantations]. 1993. - Yalta. P. 300. (in Russian)

14. Нилов, Н.Г. Стратегии орошения виноградников // «Магарач». Виноградарство и виноделие. - 2001. - №1. - С. 26-30.

Nilov, N.G.Strategiioroshenivavinogradnikov [VineIrrigation Strategies] "Magarach". Vinogradarstvo i vinodelie. ["Magarach". Viticulture and Winemaking] 2001. № 1. pp. 26-30. (in Russian)

15. Нилов, Н.Г. Предложения, направленные на интенсификацию виноградников юга Украины / Н. Г. Нилов // Агрогазета. - 2006. - № 1. - C. 1-2.

Nilov N.G. Predlozheniya, napravlennye na intensifikatsiyu vinogradnikov yuga Ukrainy. Agrogazeta. 2006. № 1. - C. 1-2. (in Russian)

16. Доспехов Б. А. Методика полевого опыта (с основами статистической обработки результатов исследований). / Б. А. Доспехов М.: Агропромиздат, 1985. - 351 с.

Dospekhov B. A. Metodika polevogo opyta (s osnovami statisticheskoi obrabotki rezul'tatov issledovanii) [Field technique]. Moscow: Agropromizdat, 1985. 351 p. (in Russian)

17. Нилов, Н. Г. Тенденции в современном растениеводстве, приводящие к необходимости организации служб мониторинга водного режима насаждений / Н. Г. Нилов // Сборник научных трудов института «Магарач». - 2001. - Т.32. - С. 9-1.

Nilov N. G. Tendentsii v souremennom rastenievodstve, privodvashchie $k$ neobkhodimosti organizatsii sluzbb monitoringa vodnogo rezbima nasazbdeniy [Trends in modern crop production, leading to the need to organize services for monitoring water regime of plantings] Sbornik nauchnykb trudov Instituta «Magarach» [Collection of scientific works of the Institute "Magarach"]. 2001. V.32. - pp. 9-11. (in Russian)

18. Кондо, И. Н. О некоторых закономерностях водного режима виноградного растения в различных климатических зонах СССР. / И. Н. Кондо, Л. П. Пудрикова // Труды. - Кишинев, - 1969. - Т. 15. - C. $65-76$

Kondo, I. N. O nekotorykh zakonomernostyakh vodnogo rezhima vinogradnogo rasteniva $v$ razlichnykh klimaticheskikh zonakh SSSR. [On some regularities of the water regime of a grape plant in various climatic zones of the USSR.]/ I. N. Kondo, L. P. Pudrikova // Trudy. - Kishinev,[Works. - Chisinau] - 1969. - T. 15. - S. 65-76. (in Russian)

19. Кондо, И. Н. Водный режим. / И. Н. Кондо, К. Д. Стоев, Л. П. Пудрикова // Физиология винограда и основы его возделывания. - 1981. - T. 1. - C. 186-238.

Kondo I. N., Pudrikova L. P. O nekotorykh zakonomernostyakh vodnogo rezhima vinogradnogo rasteniya $v$ razlichnykh klimaticheskikh zonakh SSSR [Water regime] // Fiziologiya vinograda $i$ osnovy ego vozdelyvaniya. [Physiology of grapes and its cultivation]. 1981. V. 1. pp. 186-238. (in Russian)

20. Conesa, M. R. Maximum daily trunk shrinkage and stem water potential reference equations for irrigation scheduling in table grapes / M. R. Conesa, R. Torres, R. Domingo, H. Navarro, F. Soto, A. PürezPastor // Agricultural Water Management, -2016. - V.172. - P. 51-61. 